\title{
A Study on the Role and Contribution of Women for the Development of Ayurvedic Education in Kerala
}

\author{
Anila Thomas*
}

\begin{abstract}
Education has been of central significance to the development of human society. It can be the beginning not only of individual knowledge, information and awareness, but also of a holistic strategy for development and change. Education helps an individual to develop his or her potential to the fullest, to increase the productivity and to become useful and resourceful members of the society. Education is holistic in concept and is multidimensional. Due to the technical advancement and social development, the structure of the family organization is changing. These substantial changes have created a new challenging role and status for the Indian women, especially for the middle class women. The structure of the Indian society is undergoing a metamorphosis due to Urbanisation, Westernisation, Industrialisation and Politicalisation. As a member of the family, she has to perform certain traditional roles, apart from taking an active part in economic activity. The provision of educational opportunities for girls and women has been part of the national endeavour since independence. The constitution of India, is clearly committed to the cause of education and unequivocally endorses state intervention to redress an adverse educational scenario. The recent social
\end{abstract}

\footnotetext{
* Head, Department of Tourism and Travel Management, Jyoti Nivas College (Autonomous), Bangalore-560095, Karnataka, India; anilatoms@yahoo.com
} 
changes have given an opportunity for women to enter into different developmental fields, which were once forbidden for them. The increase of educational facilities and opportunities, and the removal of traditional ban on the entry of women to particular branches and levels of education, came to be supported by all champions of women emancipation from the $19^{\text {th }}$ century. The present research work is an attempt to highlight the contributions of women in the development of Ayurvedic education in Kerala which still remains unearthed.

Keywords: Women's emancipation; Ayurvedic education-Kerala; Holistic concept

\section{Introduction}

Tourism is one of the leading Global industries (11\% of Global GDP) in the world. The world Tourism organization, estimates that there will be 1.5 billion tourists in the world by 2020, representing $21 \%$ of the world population. The strong population growth in the developing regions is set to attract almost $50 \%$ of International Tourists in 2020. The World Tourism organization notes that within the next 5 - 10 years, the range of products on offer to the tourists seeking rural experience is to increase significantly. There is a clear trend in growth of Rural Tourism, with a great increase in the number of tourists visiting these places. India's vast, rural diversity and heritage, offers tremendous potential for tourism in rural areas. Tourism is one of the major vehicles for generating sustainable livelihood in India; towards this end, the Ministry of Tourism, Government of India, UNDP India and leading NGOs are jointly developing an alternative model for rural tourism across the country, with a view to position such models as engines of economic growth. The high potential tourism sector would address the development issues, such as poverty reduction, developing vibrant local economy, revival and regeneration of arts and crafts, preservation of culture and most importantly, the gender equity. India has several forms of art and handicrafts. Contribution to national integration and the social transformation of the economic lives of people is an important feature of tourism. 
Ayurveda, the indigenous medical system of India, dates back at least 2000 years in its codified from and has roots that penetrate much deeper. "Modern Ayurveda" is understood to be geographically set in the Indian subcontinent and to commence with the process or professionalisation and institutionalisation brought about in India, by what has been called the $19^{\text {th }}$ century revivalism of Ayurveda (Leshe 1998; Brass 1972; Heffery 1988). Modern Ayurveda is characterised by a tendency towards the secularisation of Ayurvedic knowledge and its adaptation to biomedicine and at the same time by attempts to formulate a unitary theory, based on the doctrines found in the classic Ayurvedic texts. Ayurveda is a science which deals with the methods of keeping the fitness of body and spirit in order to achieve a long, healthy life. It is an ancient system of healthcare that is native to the Indian subcontinent. The term 'Ayurveda' is a Sanskrit compound word joining 'Ayus' meaning 'life' and 'veda' meaning 'knowledge' or 'science', so Ayurveda can roughly be defined as the science of life. It is not a science of medicine alone; but in its perfection, it aims at eternal life. Ayurveda is termed as life science, but it is more appropriate to call it as the "The Divine Science of Life".

Now-a-days, Kerala and Ayurveda have virtually become identical with each other; or to say in other words, Kerala health tourism is synonymous to Ayurvedic treatment. The equable climate and the natural abundance of forests, with a large variety of herbs and medicinal plants make Kerala a wonder destination for medical tourists all over the world. Kerala Ayurvedic tour packages are some of the most healing and restorative packages in India. Kerala's health tourism package offers one, an opportunity to keep aloof from their routine life of stress and strain and to live in serene relaxing surroundings.

\section{Need of the Study}

In Kerala, the Medical Tourism is synonymous to Ayurvedic Tourism; the science of life which deals with human health and longevity of life. It was envisaged by the sages of the ancient lore. These sages, by insight and intuition, during their meditation, went deep into the secrets of human physique and discovered the needs 
of the body, mind and spirit. Thus, Ayurveda is said to be a "divine science" that originated from divinity, and aims at humanity to attain divinity. As women are considered to be comforting healers, a great task is assigned to them in the practice of Ayurvedic principles. In Kerala, women had fulfilled this task by playing the role of domestic Vaidyans or family physicians for treating and curing the sickness of the members of the family. With the advent of Medical Tourism, a new venue was opened for the Kerala women to play along with their male counterparts.

Though the practice of Ayurveda progressed up to the Buddhist period in India, it was eclipsed with the onslaught of foreign invasions. But in Kerala, it retained a little glow, due to its unique traditional peculiarities and also due to the works of Ashtavaidyans. Now, Kerala is making all efforts to make Ayurvedic Tourism, a major selling product to the outer world. In the practice of Ayurvedic Tourism, Kerala women have been playing an equitable role in all its steps with men from ancient days, just as the present world medical scenario is abounded with Kerala women medics and paramedics who amass foreign currency reserve to the Government coffers.

\section{Formulation of the Problem}

Health tourism, especially Ayurvedic medical tourism, had tremendous growth, from its very beginning, in the 1980s and attracted all types of tourists, both international and domestic. Kerala has developed an independent method in the field of Ayurvedic medical treatments. In the post-independent India, women got more opportunities in the development process and Ayurvedic practice was not an exception. Women played a remarkable role, and contributed tremendously for the development of Kerala Ayurveda. Earlier, the roles of women were restricted to assistants, now many women are independent practitioners. There is a great demand for women personnel to administer the treatment for women Ayurvedic tourists and patients. This study would help in highlighting the contribution of women in developing Ayurvedic education in Kerala, which remains unearthed so far. 


\section{Objectives}

The research was intended mainly to study the role and contribution of women in the development of Ayurvedic education in Kerala.

\section{Supporting objectives}

1. To bring the women Ayurvedic practitioners to the forefront

2. To study the growth of medical tourism in Kerala from its inception

3. To study the measures taken for its progress and promotion

\section{Sample Size}

In most of the research programs, it is not possible to target each and every person, and all cannot be interviewed for this position. Sampling is necessary and there should be particular ways and procedures. Sampling is the selection of few items. The respondents selected should act as representatives of the total production. For this study, the research has been done using the sampling technique. Sampling may be known as the selection of some part of an aggregate of totality, on the basis of which judgment or inference of aggregate totality is made. It is the process of obtaining information about the entire population, by examining only a part of it. The survey done here is a non- probability sampling type. This sampling method doesn't follow any standard procedure and selects the units with unknown probability. The non-probability sampling used here is the convenience sampling. Here the researcher is selecting the sampling method, by selecting the sample units based on the researcher's convenience.

This scholar also found that the Maharajas of Travancore had played an important part in enriching the traditional treatment techniques and educating their subjects. As regards to the Travancore-Cochin areas of the State of Kerala, there existed and still exists the Travancore-Cochin Medical Practitioners Act, 1953. This law is in force from 14 October 1953 (ECA,1965) Medical practitioners belonging to all systems of medicines can get their names registered under this Act and registration is mandatory for 
any person to practice any system of medicine including Ayurveda. Now-a-days, a person who is not qualified and registered under the provisions of the Travancore-Cochin Medical Practitioners Act or the Indian Medicine Central Council Act or the Madras Medical Registration Act, cannot practice any system of Medicine in the State of Kerala.

This study addresses the respondents who are in a position to provide useful, adequate information on the subject or area of research. As statistical sampling is a methodological version of everyday experience and procedure, the samples that have been taken, ideally purports to be a miniature model of the collective, constituted by all the items that the study should principally encompass. For collecting representative data, samples are drawn at random to give due credence to the target population, i.e., women, especially the traditional knowledge holders in the field of Ayurveda in Kerala. This scholar noticed that the entry of private sector in the arena of Ayurvedic education has resulted in an increase, in the number of practitioners and academicians. An educated population can easily catch up and exploit the potential of the emerging opportunities for progress and economic advancement in the globalised environment.

This scholar has interviewed 60 academicians from various Ayurvedic Educational Institutions, both at the government and private levels, and has distributed separate questionnaires to them. Some of the questionnaires/ schedules are sent by electronic mail, because the respondents found it more convenient.

\section{Research Methodology}

The reliability, relevance and quality of research results depend largely on methodological designs used to carry out the study (Myers, D.M 1965). Traditionally, research methodologies are broadly classified into qualitative and quantitative. Myers is of the opinion that that Qualitative research is an in-depth study of social and cultural phenomena and focuses on the text, whereas Quantitative research investigates general trends across population and focuses on numbers (ECA 1965).

It is generally accepted that there are three types of considerations that influence the method a researcher will select, namely; Practical, 
Ethical and Theoretical. The considerations that influence the research methods of the present study are mainly practical and are more expressive. In the present study, the researcher has used a series of methodological pluralism involving questionnaires, indepth interviews with a number of Ayurvedic academicians and practitioners, both men and women, observation and analysis of media reports (literary and electronic media), in order to produce both statistical and in depth data (both quantitative \& qualitative data). The two main sources of data in social science research come from the inner world of library and the outside world of living people. The primary data were collected through questionnaires, schedules, observation or interview or by using two or more of these methods. The secondary data were collected from the government records, newspapers, journals and books.

\section{Primary Data}

Kerala is one of the states of the country in which Ayurveda has been an inherent part of its distinct history. Ayurveda was a major attraction for the international and domestic travellers coming to Kerala. Considering the fact that India has a wide variety of people and culture, this scholar has chosen to concentrate on the State of Kerala, since it has a very interesting ancient culture and social development. The choice of method concerning this particular study is based on the need for information about people's own experiences and interpretations of their own social situations. The study adopted both historical and analytical methodology. In Historical Methodology, the researcher considers both the investigation on past events and the viewpoints of major historians on remnants, as important "sources" or vestiges (Sreedharan, E. 2007) that will help the researcher to form a more or less subjective apprehension or view of the events he seeks to know.

Through Historical method, the true facts and events of the past and their true meaning and inter-relation are extracted from the sources of the past. Accuracy of the facts discovered depends on the criticism of the sources for which, however, knowledge of historical technique is indispensible. The researcher need not master all the historical techniques, but can borrow them from the results achieved by the experts in these different fields. 
The choice of selecting the research method depends upon the strengths or weaknesses of the method in relationship with the goals of the study. The main apparatus used was the questionnaire. Survey method has helped this scholar enormously in collecting the data directly from respondents through questionnaires from four selected districts in the state of Kerala, namely; Thiruvananthapuram, Kollam, Pathanamthitta and Ernakulam. The schedules / questionnaires were constructed in a systematic manner. The schedules were filled by this scholar in the presence of the respondent. The questionnaires were sent to the concerned persons with request of the information that was sought from them.

\section{Secondary Data}

Published works of different scholars and historians give information for the theoretical framework of the study. In order to get updated information on Ayurvedic practices of tourists in Kerala, this researcher referred to the following published and unpublished records / works; the unpublished category includes various records such as government registers, articles and research projects, maintained by both the government and private Ayurvedic institutions, hospitals and healing centres.

\section{Data Collection}

In this research process, the instrument used to collect data is the questionnaire method. Quite often, the questionnaire is considered as the heart of a survey operation. Hence, it should be carefully constructed. The study was conducted with the help of the survey method. A direct communication, accompanied with a structured questionnaire, was designed. All the trivial aspects governing the study were covered in the questionnaire. A structured set of questionnaire was presented to the sample. The questionnaire was constructed with open ended; close ended and multiple choice questions. The open ended questions allow the respondents to give all possible answers as they are not restricted; close ended, on the other hand, provides answers that are easy to interpret and tabulate. Multiple Choice Questions encourage the respondents to describe and choose the options given. After collecting the vast data, the relevant data were separated from the irrelevant data. 
Similarly, the data required for quantitative and qualitative analysis were also processed. They were then analyzed by using percentage tools and represented using bar charts and pie charts.

\section{Review of Literature}

Published works of different scholars and historians give information for the theoretical framework of the study. In order to get updated information on Ayurvedic practices in Kerala, the researcher has referred to both the published and unpublished records. The unpublished category includes various records such as government registers, articles, research projects, etc. maintained by both the government and private Ayurvedic institutions, hospitals and treatment and healing centres. Here, as the available data was insufficient and obsolete, in the case of women's contributions to the development of Ayurveda, the researcher gathered information related to the topic through observation, interviews and distribution of open ended questionnaires to a select group of cases.

Tiwari (2007) gives an insight into the power of Shakti, the divine goddess, manifested in every woman. The author has a solid understanding of ancient Indian medicine, Ayurveda that convinces, educates and broadens the perspective of the readers in the way they view their health and lifestyle. There are remedies and practices for imbalances or maladies that may occur for women which are accessible to the laywoman and practitioners alike, as well as, multiple discourses on creating possibilities for joy, peace and optimum health for every woman. It is a beautiful and concise orientation for women to access cultivating "inner medicine", the ability to heal oneself.

Wear (1996) has made an attempt to enhance our understanding of the shaping of medical education in the past, and the influence of that history on medical schools today. Women have long been segregated within the boundaries of medicine, because of their perceived capacity of compassion, first into nursing, and later into more compassionate medical fields such as paediatrics as well as those requiring better inter - personal skills. Women have entered the field of medicine in increasing numbers over the past few 
decades. However, their numbers at the general levels neither have, nor translated into equivalent numbers at the top levels of administration.

Agrawal and Aggarwal (1994) pointed out that the problem of education of girls and women acquired a new significance after the attainment of independence. The increase of educational facilities and opportunities, and the removal of traditional ban on entry of women to particular branches and levels of education, came to be supported by all champions of women's emancipation from the 19th century onwards. This volume presents a historical survey of educational planning, policies and development.

Smith (2008) provides an overview of the relatively recent history of Ayurveda in its modern and globalized forms. This book is a really good summation of contemporary Ayurveda: the colonial transformations; the formation of Ayurvedic educational institutions and associations in response to the allopathic influence; the entrepreneurial and global marketing procedures; the comprehensive outreach into Europe and the impact of Ayurveda on New Age religion.

Goel (2004) deals with theoretical perspectives of Women Development and Empowerment, and describes how education from elementary to University levels contributes a lot to the process of women development. The book also deals with economic perspectives since participation in economic activities by women can add to economic independence and thus lead to women empowerment. It also deals with women in rural development, which can make them self-reliant and co-partners in development. Education is holistic in concept and is multi-dimensional. It is a critical input in human resource development and is essential for the country's economic growth.

Flug (1992) has done a constructive study of the traditional ideas of Ayurveda, a system in ancient India, which had its supreme duty in preventing diseases and maintaining health, rather than in curing diseases. The study further deals with the methods of educating and training the practitioners in the ancient art of healing. In the late $19^{\text {th }}$ and early $20^{\text {th }}$ centuries, along with a general revival of Indian heritage, Ayurveda got a fresh thinking, 
which was then supported by the national Independence movement.

Menon (2008) has given a prolific revision of the traditional ideas related to the rich cultural heritage of Kerala. Kerala stands in the forefront of Indian states in the matter of literacy and education. The unique position which Kerala has attained in the educational map of India is not the result of a sudden spurt of activity in the field of education in recent times, but the climax of the enlightened policies followed by its rules from early days and the intellectual pursuits of the people spread over several centuries.

Forbes (2005) explained the role of Indian women, who were being educated and encouraged them to play some role in public life. These women and their colleagues who sought medical careers became part of the "new women's" network which encompassed professional women and women in the new social reform organizations. These women were forging their own identities and in doing so were sorting out, which aspects of tradition they wished to retain and which they wished to cast aside.

\section{Results and Discussion}

Before Ayurveda began its recent renewal in the West, it went through a period of decline in India, when Western Medical Education became dominant during the British rule in India. The system became a second-class option, primarily for the traditional and spiritual practitioners, and the marginalised. Recently, Ayurveda regained its lost status and new schools began to emerge. Although it remains a secondary system of health care in India, the trend toward complementary care is emerging and Western and traditional physicians often work side by side. Interest in Ayurveda in the West began during the mid 1970s as teachers from India began visiting the United States and Europe. Due to the growing recognition of Ayurveda as an alternate system of medicine, the Government of Kerala, as well as private agencies has started several Colleges in Kerala pertaining specifically to Ayurvedic education. The Kerala system of traditional treatments had developed in its own lines, through a large number of practising physicians called Vaidyans and through royal 
patronages. Some families traditionally practised this system for centuries and refined their remedies and therapies. In 1889, an Ayurvedic school was started at Thiruvananthapuram by the then Maharaja of Travancore, H. H. the Maharaja Srī Mūlami Tirunāl of Travancore, mainly for teaching Ayurveda to the members of the royal family. Later, it was taken over by the state.

A sample of 60 cases was approached with questionnaires to collect information on the role and contribution of women to the development of Ayurveda, with special focus on women in Ayurvedic education sector. The approached academicians included both male ( 34 percent) and female ( 26 percent), falling within the age group of 25-65. Some are retired from government service and they are continuing their services in the private sector. Both public and private Ayurvedic institutions were approached for gathering the data. The questionnaires were prepared in such a way that it could be answered by academicians of both public and private institutions.

About 83 percent of them acquired their knowledge and training from government Ayurvedic medical institutions. Private level Ayurvedic medical institutions have a recent origin of about ten to fifteen years. Approximately 87 percent of them found the course curriculum as satisfactory. Prior to independence, the men outnumbered the women in the gurukula system. After independence, the situation changed a lot and female students outnumbered the males, even at the post-graduation level.

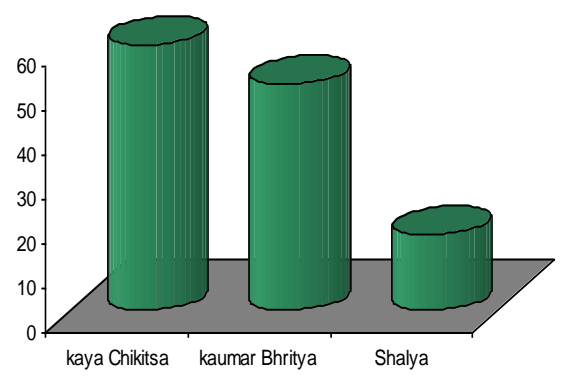

Fig. 1. Women Specialised Treatments

The approached respondents are of the opinion that Kaya Chikitsa (cent percent), Kaumara Bhritya (85\%) and Shalya Tantra (25\%) are 
the preferred areas by women for specialisation in the field of Ayurveda. The study (Fig 1) shows that Kaya Chikitsa and Kaumara Bhritya are the two main specialized areas of Ayurveda which are mostly preferred by women for higher studies.

About 60 percent of the respondents are of the opinion that parents' Ayurvedic medical milieu is not an influencing factor that decide whether parents send their daughters for Ayurvedic courses or not. Almost every approached academician agreed that the number of Ayurvedic educational institutions is also increasing in Kerala and they also believed that the emergence and development of the educational institutions have produced many women practitioners in the society.

Many women came forward to join the various courses offered in these institutions. The social and family set up also supported them to a certain extent. High literacy rate of Kerala, government's strategies for empowerment of women, economic deliverance, and so on also have a strong influence in the transition of women's status in the field of Ayurveda in Kerala.

It is believed that the number of women personnel is increasing and the main reasons for this change are the introduction of educational institutions, legal support to women's rights, and economic awareness and stability. Other reasons highlighted were better job environment compared with the other schools of medicine and lesser number of complicated and emergency cases.

Some of the private and government institutions have started giving awareness programmes to selected rural regions, especially to local self- help groups. They are of the opinion that these measures can help in solving problems related to lack of sufficient quantity and quality of the medicinal ingredients. Moreover, the people who are involved in the business do not need any standards to be fulfilled.

They only need the knowledge and training in Ayurvedic medical field, which can be gathered from awareness programmes and also guidance from practitioners and academics. The approached respondents also reported that they have come across certain encumbrances like family circumstances (40 percent), social 
constraints (40 percent) and marginalised career opportunities (20 percent) (Fig. 2).

The approached academicians suggested that measures such as supporting the specialists who are economically weak (97 percent) and acknowledging the specialists and experts with exceptional knowledge (35 percent) (fig. 3) can be used for rejuvenating the traditional and unique system of Ayurveda in Kerala.

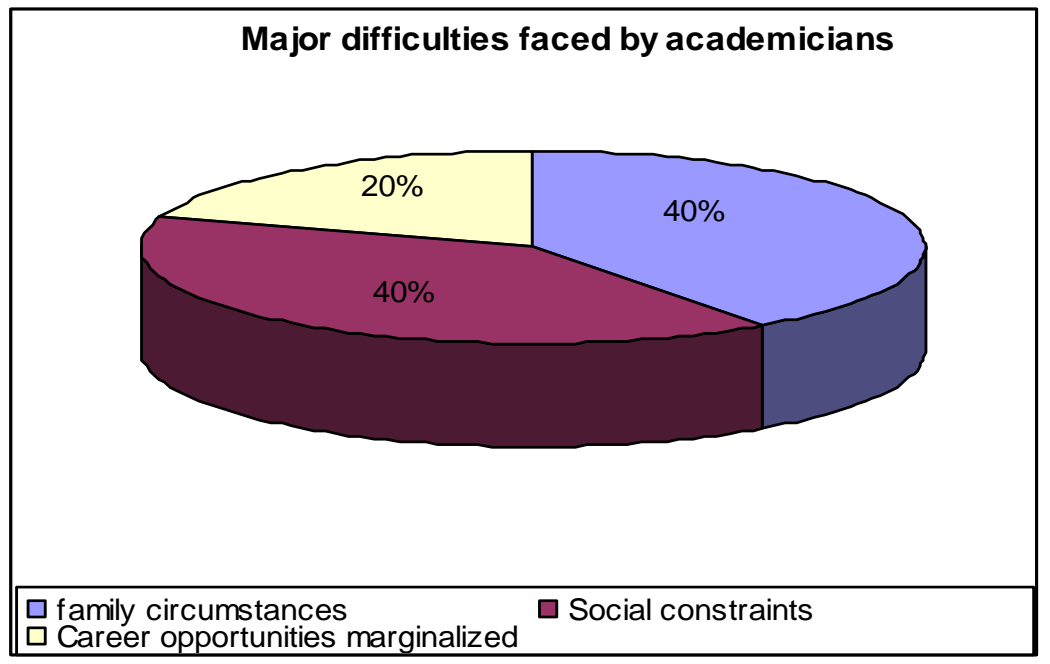

Fig. 2. Difficulties faced by academicians

As academicians and practitioners, they found that identifying the traditional experts in this field can be the main remedial measure to rejuvenate the traditional medical practice of Kerala. All these measures disclose that Ayurvedic Medical Tourism in Kerala has a bright future ahead. Indeed, women are playing a vital role for this venture. Imparting knowledge which is related to the natural way of curing, and introduction of more specialised areas under various Ayurvedic courses (77 percent) are the prime factors that helped the Ayurvedic Educational Institutions in promoting Ayurvedic Medical Tourism in Kerala. 


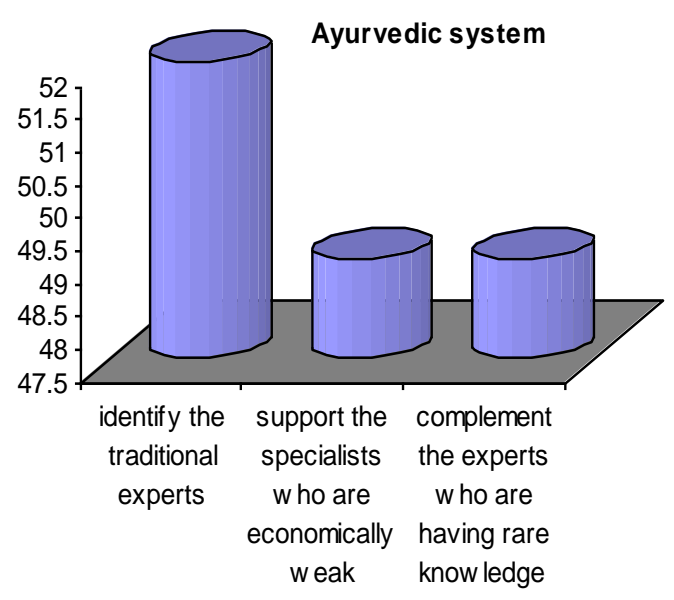

Fig. 3. Remedial measures to rejuvenate the Kerala traditional Ayurvedic system

The growth of the role of women in education and medical fields is tremendous in Kerala, when compared to that of the other states. As per the 2001 Census, the percentage of women literacy in Kerala was 87.7 percent, while the Indian average was 55 percent and had a second position in its state ranking (Report of the Steering Committee on Empowerment of Women and Development of Children for the 11th Five Year Plan (2007-2012). At the same time, the number of females in higher education sector surpassed the number of males from 60 to 87 percent except in Engineering, medicine, ITI or ITC courses. There are now 14 Ayurveda colleges in Kerala, of which 3 are in Government Sector, 2 are in private sector and 9 are in self-financing sector. These colleges have an annual intake of 680 students for BAMS courses and 82 students for postgraduate courses (Directorate of Ayurveda, Thiruvananthapuram). The percentage of males in medical education in 1980 was 90 percent and of females was only 10 percent.

Prior to the starting of a separate Ayurvedic education institution in Thiruvananthapuram in 1850, its practice and training was limited to the traditional practitioner's discretion. The practitioner will decide whether to pass the knowledge and expertise to the coming generations. It was a kind of gurukula system of education, which prevailed during the early days of its development, and women got very less opportunity to take part in it. The first 
Ayurveda College at government level in Kerala was established in Thiruvananthapuram in 1897. In its early stages of establishment, very rarely one could find female students in the classes. But after India's independence, around the 1950s, the situation had changed and the number of female students in the classes increased. During 1970-75, out of the 70 students, 7 were girls. But now the situation has entirely changed (Information collected from Dr. N. Sati, BAM, Chenivila Ayurveda hospital, Pathanapuram, Kollam District). Around 1980s, 30 percent of the students were girls and by 200007, only 10-15 percent are boys (Information collected from Dr. Sreela Vipin, Ayushree Ayurveda Hospital, Pathanapuram, Kollam District).

Now many parents are coming forward to educate their daughters in Ayurvedic institutions. Almost 95 percent of the students are women in each Ayurveda college and similar is the number in all Paramedical courses. The data collected from Nangelil Ayurveda college shows that the number of female students for B.A.M.S. Bachelor of Ayurvedic Medicine and Surgery (Ayurvedacharya) has been increasing since its inception in 2002.

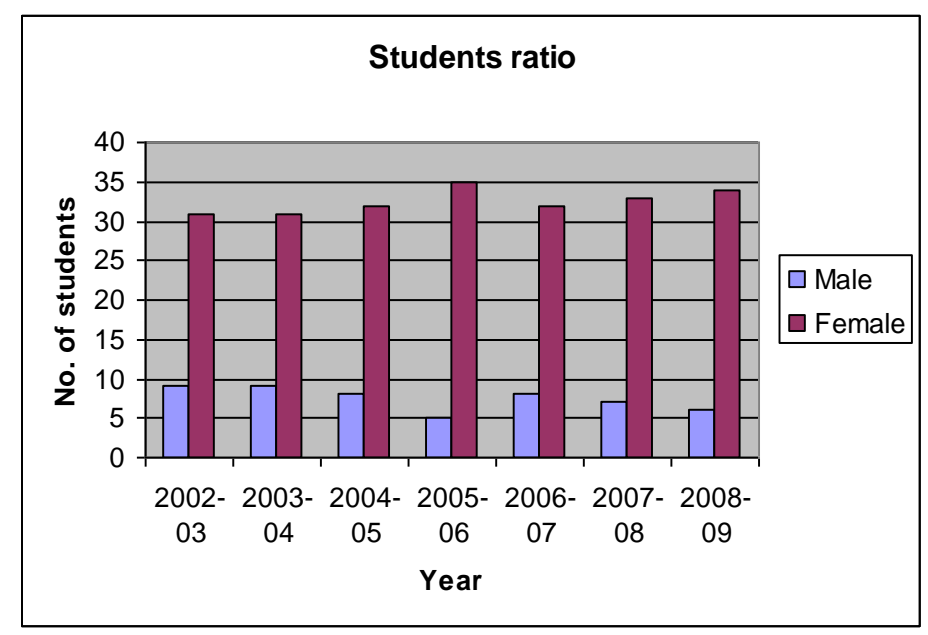

Fig. 4. Student ratio

(Source: Interview with Vijith Nagelil, B.A.M.S, Administrator, Nangelil Ayurvedic College Kothamangalam, Ernakulam) 


\section{Findings of the Study}

The findings of the research are summarised, arranged and presented in the chapter.

The major findings of the study are as follows:

1. Women are playing a very good role in the promotion of Ayurveda. The reasons highlighted were better hospitality and management skills, punctuality, regularity, and also have more patience. They were considered to be rendering better services.

2. Now-a-days, opportunities for women are more in the field of Ayurveda. Economically, people are more stable now, because of that more freedom is given to women regarding higher learning, career and life itself, compared to earlier times.

3. The number of women personnel is increasing in the field of Ayurveda. The main reason highlighted was better job environment compared to the other schools of medicine. Very less number of complicated or emergency cases are coming to Ayurvedic practitioners; so, risk factor is very less in this field. Anaesthesia, surgery, etc. are not so common in Ayurvedic treatments.

4. The process of curing is very slow and the treatments have no side effects. Areas where the other schools of medicines are unable to bring the required results to the patients are also relying on Ayurvedic treatments.

5. In Ayurvedic educational institutions, the number of women students is increasing considerably.

When the opinion of the respondents on the role of women in the field of Ayurveda are being analysed, it is found that, with the support of an independent, indigenous Ayurvedic treatment system, women played a remarkable role and contributed tremendously for the development of Ayurvedic education in Kerala. The major findings of the analysis were as follows: 
- Earlier role of women was restricted to assistants; but, nowadays they are practicing more independently.

- Women have always been part of the development process with different roles, and currently women independent practitioners have more significance.

Thus, the synchronized efforts of public and privatised Ayurvedic medical institutions have facilitated women to accomplish a remarkable role and contribute tremendously for the development of Ayurvedic education in Kerala.

\section{Suggestions and Recommendations}

1. To attract the present requirements of the foreign tourists, Ayurvedic packages should be given its due share of attention.

2. Kerala Ayurvedic packages should be publicised widely in foreign countries using the visual media.

3. Measures to be taken to create an apposite culture throughout the state giving public awareness.

4. Strict legislation for quality control and safety of patients cum-tourists must be made and implemented with iron will, and violation must be dealt with seriously. Orientation courses at intervals should be given to the Ayurvedic personnel, so as to give maximum satisfaction to the tourists.

5. A separate research wing may be instituted to replace present commercialized treatment. The traditional indigenous system must be revoked to be used in the present practice.

6. Local bodies like Panchayats and Municipalities should take action to participate in the promotion drive by starting pharmaceutical units, so as to produce medicines by utilizing the services of "Kudumbasree" or "Ayalkoottam" at the various stages of preparation of medicines. 


\section{Conclusion}

Now Ayurveda is sought after as a gentle healing system, which leads to a long and healthy life, by people in and outside India. In this "high-tech age", the world has shrunk to one global village, and the use of Ayurvedic medical treatment can be made accessible to the global man. As travel has become a popular leisure activity, people from western countries opt to come to India to spend their leisure time and to undergo treatments which are highly expensive in their home countries. The state of Kerala which proudly bears the caption of "Gods own country" can be a dear tourism destination for foreigners, if wide publicity is given, by highlighting the attractive packages of medical tourism combined with leisure travel. It has already been in vogue that, in the field of tourism, Kerala is ranked first among the Indian states, and also Kerala is one of the ten "must see destination" of the world. The most favourable factors for Kerala as health tourism destination are its authenticity in rich Ayurvedic healthcare heritage with multifaceted attractions. Women in Kerala are playing a very tremendous role in the promotion of Ayurveda. The reasons highlighted were better hospitality and management skills, punctuality, regularity, and also have more patience. They were considered to be rendering better services. Nowadays, opportunities for women are more in the field of Ayurveda. As economically people are more stable, more freedom is given to women regarding higher learning, career and life itself, compared to earlier times "Kerala has an immense potential to develop the scope of health tourism in the country. It can become the hub and one of the most preferred destinations in the world for potential health tourists," Sri Lankan minister for minor export crop promotion Reginald Cooray saidi. He was inaugurating the twoday international conference and exhibition on health tourism, Kerala Health Tourism 2011, organized by the Confederation of Indian Industry (CII) at Hotel Le Meridian on 21 October 2011. The three-day Global Investment Summit, “Emerging Kerala 2012" held at Le Meridian in Kochi from September 12 -14, 2012 put forth many development projects to attract the investors globally. In the plenary session of the Summit, Kumari Selja, the Union minister for Housing and Urban Poverty Alleviation said that Kerala had 30 
key Public Private Partnership (PPP) projects with an accumulated investment of Rs. 150 billion. State health minister Mr. V. S. Shivakumar, who chaired the session for "Healthcare Sector in Kerala - Emerging Scenario" declared that the state government has decided to set up a Rs. 200 Crores "Global Ayurveda Village" with a well equipped treatment centre at Ponmudi, near Thiruvananthapuram through PPP, and appointed KINFRA as a nodal agency to acquire 200 acres for the sameii. This was based on the agenda for global acceptance of Ayurveda and so, to transfer Kerala into a world capital of Ayurveda.

The elevation of economic status of the population at the higher level and the better literacy rate has helped the people to be more aware of the need of a healthy living. Needless to say, leaps and bounds of Ayurveda among the healthcare methods are ascribed to Panchakarma therapies. Ayurveda resorts are providing treatments for ailments such as arthritis, paralysis, obesity, sinusitis, migraine, and skin ailments. A sincere commitment to these co-ordinated moves allows each stakeholder to focus on his or her own competencies and may alleviate the level of competition - allowing for a better long run revenues throughout the entire sector.

\section{References}

Agarwal, S. P., \& Agarwal, J. C. (1994). Women's education in India. New Delhi: Concept Publishing Company.

Flug, B. P. (1992). Education in Ayurveda: A re-constructions analysis. New Delhi: Gyan Publishers.

Forbes, G. H. (2005). Women in colonial India: Essays on politics, medicine and historiography. New Delhi: Chronicle Books.

Goel, A. (2004). Education and socio-economic perspectives of women development and empowerment. New Delhi: Deep \& Deep Publications

Menon, S. A. (2008). Cultural heritage of Kerala. Kottayam: D. C. Books.

Myers, D. M. (2009). Qualitative research in business and management. London: Sage Publications

Report by expert committee on ayurveda. (1965). Thiruvananthapuram: S G P, Government Press. 
Smith, F. M., \& Wujastyk, D. (2008). Modern and global ayurveda: Pluralism and paradigms. New York: State University of New York Press.

Sreedharan , E. (2007). A manual of historical research methodology.. Trivandrum : Centre for South Indian Studies.

Tiwari, M. (2007). Women's power to heal through inner medicine. New York: Alibris.

Wear, D. (1996). Women in medical education: An anthology of experience. New York: Suny Press. 
